\title{
Statyba
}

\section{AN EXPERIMENTAL INVESTIGATION OF ACOUSTIC PARAMETERS OF THE LABORATORY FOR MEASURING SOUND INSULATION OF BUILDING ELEMENTS}

\section{Dikavičius \& R. Bliūdžius}

To cite this article: V. Dikavičius \& R. Bliūdžius (2001) AN EXPERIMENTAL INVESTIGATION OF ACOUSTIC PARAMETERS OF THE LABORATORY FOR MEASURING SOUND INSULATION OF BUILDING ELEMENTS, Statyba, 7:2, 166-173, DOI: 10.1080/13921525.2001.10531718

To link to this article: https://doi.org/10.1080/13921525.2001.10531718

曲 Published online: 30 Jul 2012.

Submit your article to this journal $₫$

III Article views: 56 


\title{
STATINIO ELEMENTU GARSO IZOLIACIJAI MATUOTI SPECIALIAI IRENGTOS LABORATORIJOS AKUSTINIŲ PARAMETRŲ TYRIMAS IR DERINIMAS
}

\author{
V. Dikavičius, R. Bliūdžius \\ Architektūros ir statybos institutas
}

\section{Ivadas}

I pastato vidụ triukšmą labiausiai praleidžia langai ir durys. Kad triukšmo lygis patalpoje būtų mažesnis už leistiną, reikia ivertinti aplinkos triukšmo lygi jau projektuojant statinị tam, kad būtų galima parinkti langus ir duris. Taigi akivaizdu, kaip svarbu tiksliai išmatuoti šiu statinio elementų oro garso izoliacijos koeficientą. Architektūros ir statybos institute Statybinès šiluminès fizikos laboratorijoje buvo suprojektuota ir irengta laboratorija, skirta pastatu elementų oro garso izoliacijai matuoti.

Svarbiausi reikalavimai, keliami laboratorijos fiziniams matmenims, akustiniams parametrams, matavimo tikslumui, suformuluoti standartuose [1-3]. Pagrindinis šio darbo tikslas buvo eksperimentais nustatyti, kaip akustiniai parametrai bei matavimo tikslumas atitinka standartụ reikalavimus, o neatitikties atveju - juos koreguoti, kad atitiktų šiuos reikalavimus.

\section{Tyrimai ir rezultatų aptarimas}

\subsection{Tyrimo objektas}

Bendras laboratorijos vaizdas (du pjūviai ir skiriamosios sienos konstrukcija) pateiktas 1, 2 pav. Kaip matome iš bréžinio, laboratorija susideda iš dvieju patalpu, perskirtu dviguba betonine siena, ir patalpos, skirtos matavimo aparatūrai. Laboratorija irengta rekonstruotoje jau pastatyto statinio dalyje. Kadangi netaisyklingos formos patalpu statybai būtu prireikę daug daugiau lèšŭ, buvo pasirinkta pusiau netaisyklingu patalpu forma: abieju patalpu lubos pakopomis leidžiasi žemyn nuo kraštiniu sienu dvigubos skiriančiosios sienos link. Šios dvi gretimos patalpos (aidinčios kameros) pastatytos ant atskirų pamatų ir yra apgaubtos išorinio statinio, taip pat pastatyto ant atskiru pamatų. Aidinčios kameros tarpusavyje ir išorinio statinio atžvilgiu akustiš- kai izoliuotos $7 \mathrm{~cm}$ storio akmens vatos plokštemis. Tokia konstrukcija leidžia sumažinti netiesiogini garso pralaidumą tarp aidinčių kameru, be to, šios kameros izoliuojamos nuo išorinio triukšmo ir tai minimizuoja fonini triukšmą jose. Kameras skiriančioje dviguboje sienoje, kurios storis $200 \mathrm{~mm}$, yra dvi angos - viena langui istatyti $(1510 \mathrm{~mm} \times 1258 \mathrm{~mm})$, kita - durims $(910 \mathrm{~mm} \times 2100 \mathrm{~mm})$. Bandant vieną iš šių bandinių, kita anga būna uždengta izoliacine medžiaga, kurios garso izoliacija artima skiriamosios sienos izoliacijai.

Norint išmatuoti sienos garso izoliaciją, būtina išardyti aidinčias kameras skiriančias sienas ir ant vienos iš jụ pamatu pastatyti norimą ištirti sieną. Kairiają (mažesnę) patalpą sąlygiškai pavadinsime priimamojo garso kamera, o dešiniają (didesnę) - siunčiamojo garso kamera; jų tūriai atitinkamai yra $V_{i}=68,5 \mathrm{~m}^{3}$ ir $V_{s}=79,9 \mathrm{~m}^{3}$, nors reikalaujami minimalūs tūriai [1] turi būti ne mažesni kaip $50 \mathrm{~m}^{3}$. Siunčiamojo garso kameros tūris $V_{s} 14 \%$ didesnis už priimamojo garso kameros türi, nors rekomenduojamas [1] bent $10 \%$ skirtumas.

\subsection{Matavimo ïranga}

Realaus laiko garso spektro analizatorius $2800 \mathrm{~B}-$ Larson\&Davis;

mikrofonas 2560 - Larson\&Davis;

mikrofoninis pradinis stiprintuvas PRM $900 \mathrm{C}-$ Larson\&Davis;

mikrofono pasukimo irenginys (pagamintas vietoje);

galios stiprintuvas su 20 reguliuojamų filtrų (pagamintas vietoje);

mikrofono kalibratorius CAL 200 - Larson\&Davis;

visakryptis dvylikasienis garsiakalbis (gamintas vietoje). 

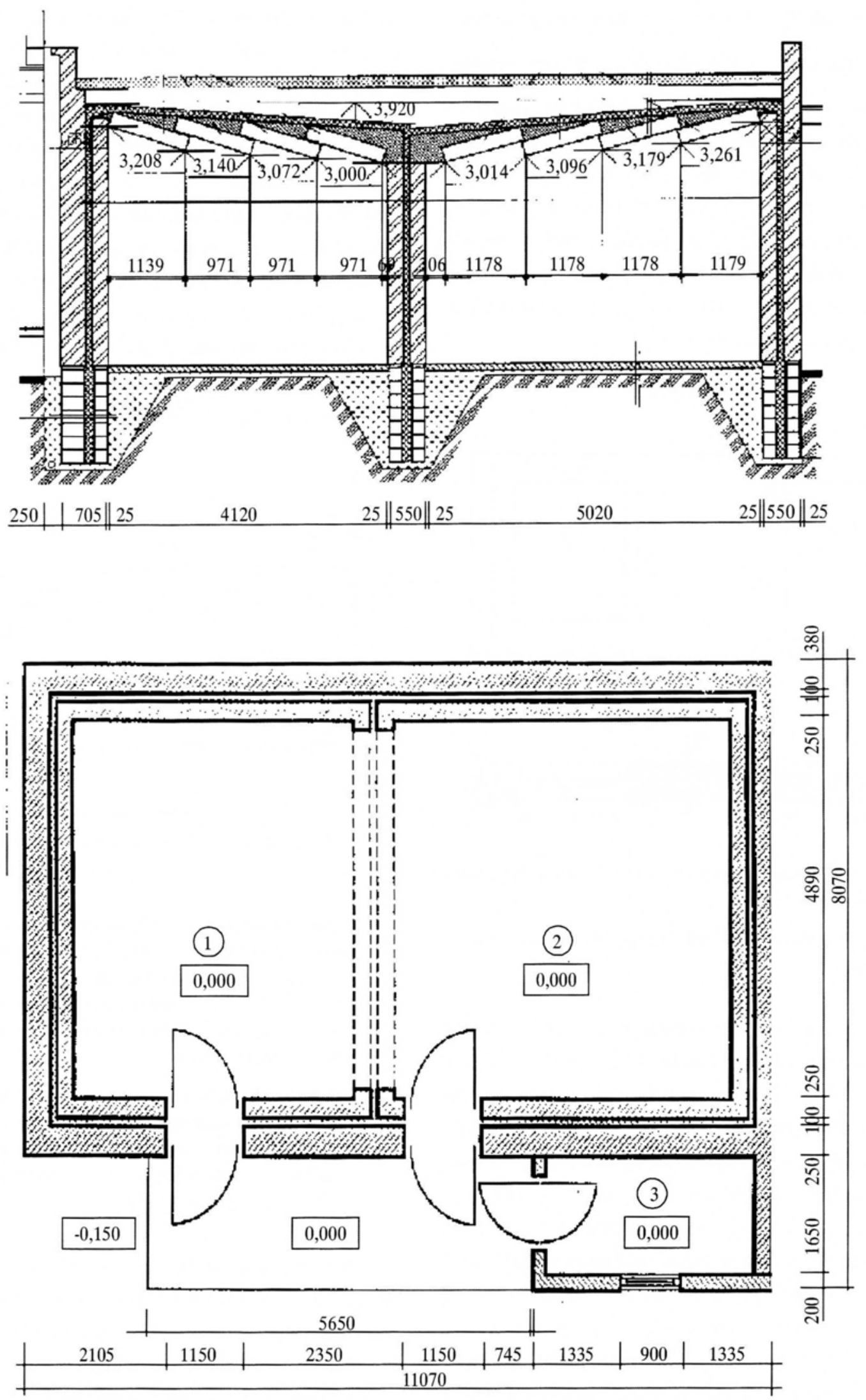

1 pav. Bendras laboratorijos konstrukcijos vaizdas: 1 - vertikalusis išilginis pjūvis; 2 - horizontalusis pjūvis Fig 1. The general view of the laboratory: 1 - vertical and longitudinal cross-section; 2 - horizontal crosssection 


\section{Eksperimentinis tyrimas ir rezultatų aptarimas}

\subsection{Aidėjimo laiko matavimas ir korekcijos paieškos}

Vienas iš aidinčias kameras apibūdinančių akustiniu parametru yra aidejimo laikas $T_{r}$, kuris yra apibrèžiamas kaip laikas, per kuri garso lygis kameroje, išjungus garso šaltini, sumažeja $10^{6}$ karto. Aidejjimo laikas buvo skaičiuojamas pagal Sabine pasiūlytą išraišką [4]. Kaip reikalaujama standarte [1], jis neturi būti pernelyg ilgas ar trumpas. Leistinos $T_{r}$ ribos žemiesiems dažniams nustatomos nelygybe:

$$
1 s \leq T_{r} \leq 2 \cdot(V / 50)^{2 / 3} s .
$$
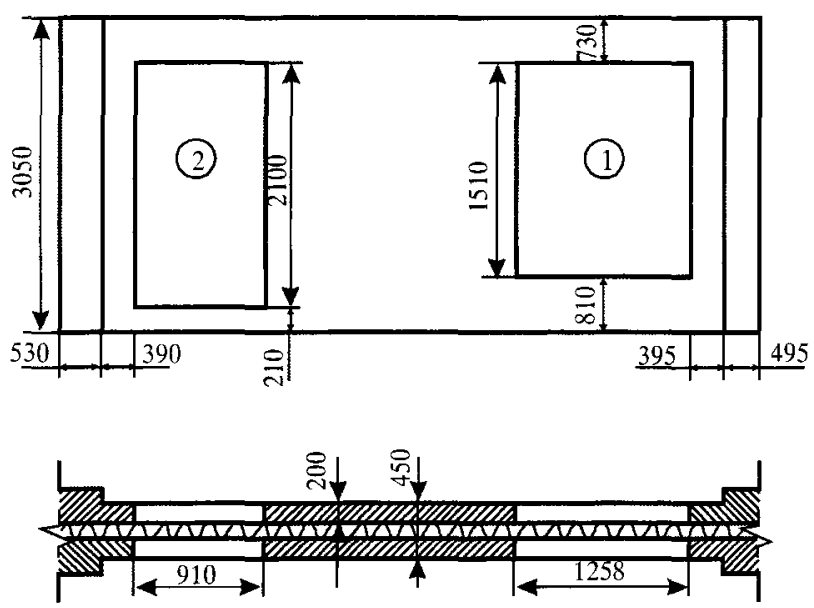

2 pav. Patalpas skiriančios sienos ir angu bandiniams istatyti schema

Fig 2. Construction of the filling wall and openings for specimens

I šią nelygybę irašę kameru tūrių vertes gausime, kad aidejjimo laikas turètu būti $1 s \leq T_{r} \leq 2,4 s$ ir $1 s \leq T_{r} \leq 2,734 s$ atitinkamai priimamojo garso ir siunčiamojo garso kamerose. Norint aidejjimo laiką išmatuoti kiekvienoje kameroje, jas skiriančioje sienoje esančios angos buvo užpildytos izoliacine medžiaga (medžio drožlių plokštès pakaitomis su akmens vatos plokštèmis). Aidejjimo laikas buvo nustatomas kiekvienoje $1 / 3$ oktavos dažnių juostoje nuo $100 \mathrm{~Hz}$ iki $3150 \mathrm{~Hz}$, naudojant užrašymo režima, leidžiantị vienu metu ịrašyti garso lygio kritimo kreives visose dažnio juostose. Aidejjimo laikas buvo matuojamas, sužadinant garsiakalbi per galios stiprintuvą „rožiniu“ triukšmu tam, kad būtų užtikrinta vienoda garso energija, tenkanti $1 / 3$ oktavos dažnio juostai visu tiriamu dažniụ diapazonu $(100 \mathrm{~Hz} \div 3150 \mathrm{~Hz}$ ), analizei naudojant vienodos pro- centinès dažnio juostos $1 / 3$ oktavos filtrus. Vidutine erdvinè aidejjimo laiko reikšmé buvo apskaičiuojama naudojant spektro analizatoriaus vidutinès reikšmès radimo funkciją iš skirtinguose kameros taškuose užrašytų garso kritimo kreivių. Išmatuotos aidejjimo laiko reikšmès tuščiose kamerose (3 pav. 1, 2 kreivès) labai viršijo leistinas ribas. Tam, kad būtų sumažintas aidejjimo laikas esant žemiesiems dažniams, ant abiejų kamerų sienų atsitiktine tvarka buvo pritvirtinti keturi žemujų dažnių sugèrikliai. Šie sugèrikliai susideda iš medinio rèmo $(950 \times 650 \times 50) \mathrm{mm}$ su pritvirtinta $4 \mathrm{~mm}$ storio fanera, o vidinis jo tūris tarp sienos ir faneros užpildytas stiklo vata (3 pav. 3,4 kreivès).

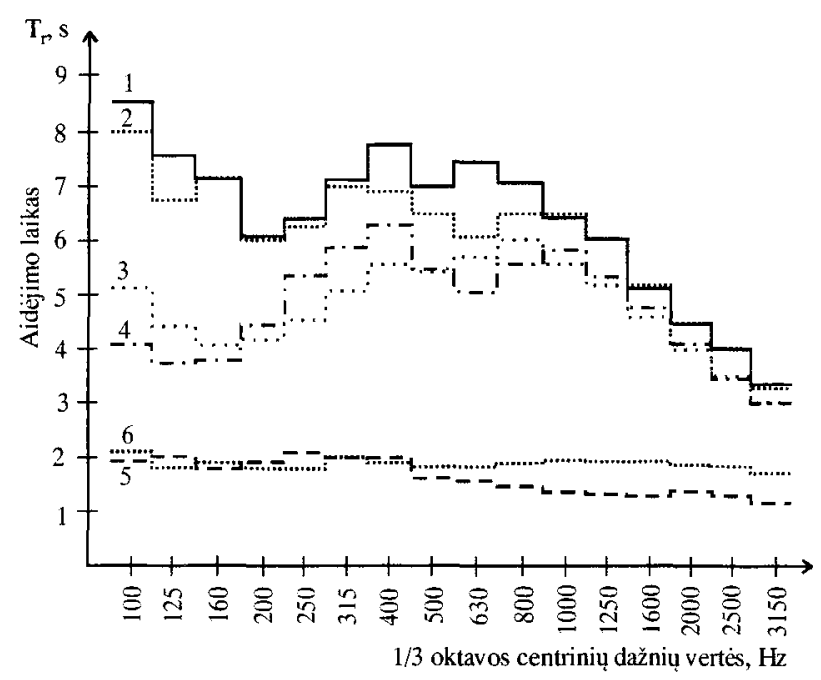

3 pav. Aidèjimo laiko priklausomybè nuo dažnio: 1, 2 tuščiose priimamojo ir siunčiamojo garso kamerose; 3,4 - priimamojo ir siunčiamojo garso kamerose su keturiais žemojo dažnio rezonansiniais sugèrikliais; 5, 6 - priimamojo ir siunčiamojo garso kamerose po galutinio suderinimo aidejimo laiko

Fig 3. The reverberation time frequency dependence: 1, 2 - in empty receiving and source room; 3, 4 - receiving and source room with four resonance absorbers installed in each room; 5,6 - receiving and source room after final adjustment

Iš 3 ir 4 kreivių matyti, kad aidejjimo laikas žemųjų dažnių 1/3 oktavos juostose labai sumažèjo, tačiau nepakankamai, kad tenkintų nelygybe (1) nustatytas ribas. Norint gauti reikiamas aidejjimo laiko reikšmes visose dažniu juostose, garsą priimančioje kameroje teko pritvirtinti iš viso 8 žemojo dažnio rezonatorius, o siunčiamojo garso kameroje - 5. Be to, norint padidinti akustinio lauko difuziškumą, kamerų erdveje atsitiktine tvarka buvo pakabinta po tris difuzorius. Norint mini- 
mizuoti stovinčias bangas, abiejose kamerose prie dviejų šninių sienu tam tikru kampu buvo atremti gipso kartono lakštai $(2500 \times 1200) \mathrm{mm}$. Siekiant sumažinti aidèjimo laiką esant vidutiniams ir aukštesniesiems dažniams ant grindụ ir kamerų kampuose detos stiklo vatos plokštés $(1000 \times 500 \times 50) \mathrm{mm}$. Aidèjimo laiko reikšmès, gautos naudojant korekcines priemones, pateiktos 2 pav. (5, 6 kreivès).

\subsection{Foninio triukšmo lygis}

Foninio triukšmo lygis priimamojo garso kameroje - vienas iš svarbesnių akustinių parametrų, kuris leidžia išmatuoti didele garso izoliacija pasižyminčių statinio elementu (sienos) garso izoliacijos indeksą. Kaip yra reikalaujama standarte [3], foninis triukšmo lygis turètu būti bent $6 \mathrm{~dB}$ (pageidautina daugiau nei $15 \mathrm{~dB}$ ) mažesnis už priimamojo garso ir foninio triukšmo kombinaciją. Foninio triukšmo lygis priimamojo garso kameroje buvo matuotas šešiuose erdvès taškuose keičiant mikrofono padèti distanciškai valdoma mikrofono pasukimo sistema, leidžiančia pasukti mikrofoną $30^{\circ}$ diskretiškumu. Mikrofono svirties sukimosi plokštuma su grindu plokštuma sudarè $30^{\circ}$. Mikrofono svirties lygis, skaičiuojant nuo ašies, sudarè $1200 \mathrm{~mm}$. Išmatuoto foninio triukšmo lygio priklausomybè nuo dažnio parodyta 4 pav.

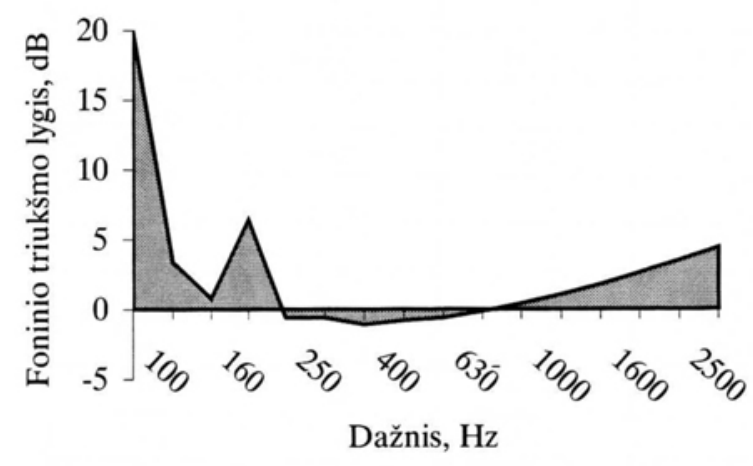

4 pav. Foninio triukšmo lygis priimamojo garso kameroje

Fig 4. Background noise level in the receiving room

Foninio triukšmo lygio priklausomybès nuo dažnio grafike galima matyti du pikus $100 \mathrm{~Hz}$ ir $200 \mathrm{~Hz} 1 / 3$ oktavos pločio dažnių juostose. Šio triukšmo šaltinis yra elektros transformatorius, stovintis transformatorinèje, esančioje šalia akustinès laboratorijos. Tai elektros tinklo dažnio mechaninių virpesių $100 \mathrm{~Hz}$ ir $200 \mathrm{~Hz}$ harmonikos, patenkančios i kamerą per žemę ir pama- tus, kadangi tarp laboratorijos ir transformatorinès kitu konstrukcinių ryšių nėra. Tačiau šie triukšmo pikai gali būti toleruojami, kadangi egzistuoja nemažas sistemos galios stiprintuvas - garsiakalbis garso signalo generavimo rezervas (tiriamu dažnių diapazonu bendras garso lygis gali viršyti $100 \mathrm{~dB}$ ). Likusiose dažniu juostose foninio triukšmo lygis labai mažas ir tai potencialiai galètų užtikrinti reikiamą matavimų tikslumą.

\subsection{Optimaliụ garsiakalbio padėčių nustatymas}

Siekiant minimizuoti sistemines matavimo paklaidas reikia sukurti kiek galima difuziškesni akustini lauką, kuris veikia bandomajj objektą. Lauko difuziškumas priklauso nuo kameros geometrijos, garsiakalbio kryptingumo difuzoriu skaičiaus bei jų orientacijos erdvèje. Egzistuoja tam tikras metodinis neapibréžtumas, t. y. ne visai aišku, kokiu eiliškumu derinimo procedūra turètụ būti atliekama. Kaip rekomenduojama standarte [1], reikiamas atsitiktiniu būdu kameros erdvèje orientuotų difuzoriu skaičius yra nustatomas bandymu. Reikia vis didinti difuzoriu kieki, lygiagrečiai matuojant garso izoliacijos indeksą, kol pasiekiama minimali ir nekintama indekso vertè nepriklausomai nuo tolesnio difuzoriụ skaičiaus didinimo. Laikoma, kad nuo to momento, kai garso izoliacijos koeficientas daugiau nemažèja, difuzorių skaičius yra pakankamas. Kitas būdas siunčiamojo garso kameroje pasiekti maksimalų difuziškumą remiasi optimalių garsiakalbio padèčių pasirinkimu, keičiant jo padeti atsitiktine tvarka orientuotu difuzorių atžvilgiu. Tai turètu būti atliekama tokia tvarka: 1 - i kameras itraukiamas tam tikras difuzoriu skaičius; 2 - ieškomos optimalios garsiakalbio pozicijos siunčiamojo garso kameroje; 3 - išmatuojamas garso izoliacijos indeksas; 4 - itraukiamas papildomas difuzorių skaičius; 5 - kartojami 2, 3 žingsniai; 6 - stebima, ar sumažejo garso izoliacijos indekso reikšmè. Jei taip, ciklai kartojami, jei ne - atliekamas 2 žingsnis. Toks akustinio lauko difuziškumo maksimizavimo nuoseklumas būtu optimalus. Mes pasirinkome paprastesni kelią tardami, kad iš dalies netaisyklinga kameru forma ir 5-ių difuzorių, itrauktų i kiekvieną kamerą, skaičius, potencialiai turètų užtikrinti lauko difuziškumą, jo minimizavimui paliekant tik dali pateiktos veiksmų sekos, t. y. garsiakalbio optimalių padéčių suradimo procedūra, kurią mes eksperimentiškai atlikome vadovaudamiesi standarte [3] pateikta metodika. Prieš tai 
Kauno Mikrosistemų ir natotechnologijų mokslinio centro beaideje akustinejje kameroje buvo nustatyta garsiakalbio kryptingumą apibūdinančio kryptingumo indekso priklausomybė nuo garsiakalbio pasukimo kampo. Gauti rezultatai patvirtino, jog garsiakalbi galima laikyti spinduliuojančiu nagrinèjamu dažniu diapazonu tolygiai visomis kryptimis. Tai irgi reikia priskirti prie sąlygu, didinančiu lauko difuziškumą. Garsiakalbio padèčių skaičius, kuris turètų būti ištirtas, apibrẻžiamas išraiška [3]:

$$
m=152 V_{s}^{2 / 3} \text {. }
$$

Mūsų atveju $m=8$. Remiantis optimaliu garsiakalbio padéčiu atrinkimo metodika [3] buvo pasirinktos aštuonios garsiakalbio pozicijos. Kiekvienoje ju buvo nustatomas skirtumas $D$ tarp laike ir erdveje suvidurkintų garso slégio lygių siunčiamojo garso ir priimamojo garso kamerose šešiose 1/3 oktavos dažnių juostose su centriniais dažniais nuo $100 \mathrm{~Hz}$ iki $315 \mathrm{~Hz}$. Šių skirtumų standartinis nuokrypis minėtose šešiose dažnių juostose skaičiuojamas taip:

$$
S_{i}=\left[\frac{1}{m-1} \sum_{j=1}^{m}\left(D_{j, i}-\mu_{i}\right)^{2}\right]^{1 / 2},
$$

$D_{i j}$ - lygių skirtumas $j$-ajai garsiakalbio paděčiai $i$-tojoje $1 / 3$ oktavos dažnio juostoje; $\mu_{i}$ - lygių skirtumo aritmetinis vidurkis $i$-ojoje $1 / 3$ oktavos dažnio juostoje.

Praktikoje naudotinų garsiakalbio pozicijų skaičius $N$ yra nustatomas iš nelygybiu [3] $N \geq 2$, $N \geq\left(s_{i} / \sigma_{i}\right)^{2}, \quad N \geq\left(\sum_{i} s_{i} / 4,8 d B\right)^{2}, \quad \sigma_{i}$ - priskirtas maksimalus standartinis vidutinès reikšmès nuokrypis esant $N$ garsiakalbio padèčiu, kuriu reikšmès šešiose $1 / 3$ oktavos dažniu juostose $(100 \mathrm{~Hz} \div 315 \mathrm{~Hz})$ pateiktos lentelèje [3]. Reikalaujama, kad tuo atveju, kai $2 N>m$, garsiakalbio tiriamų vietų skaičius turi būti padidintas nuo $m$ iki $2 N$. Apskaičiavus gauta, kad $N=8$, taigi tiriamų garsiakalbio vietų skaičius turètų būti padidintas iki 16. Buvo parinkta septyniolika galimu garsiakalbio padéčiụ ir atlikti garso lygio matavimai.

1 lentelè. Garso lygių skirtumai $D_{i j}, \mathrm{~dB}$ ir statistinių dydžių vertès

Table 1. Differences in levels $D_{i j}, \mathrm{~dB}$ and statistical values

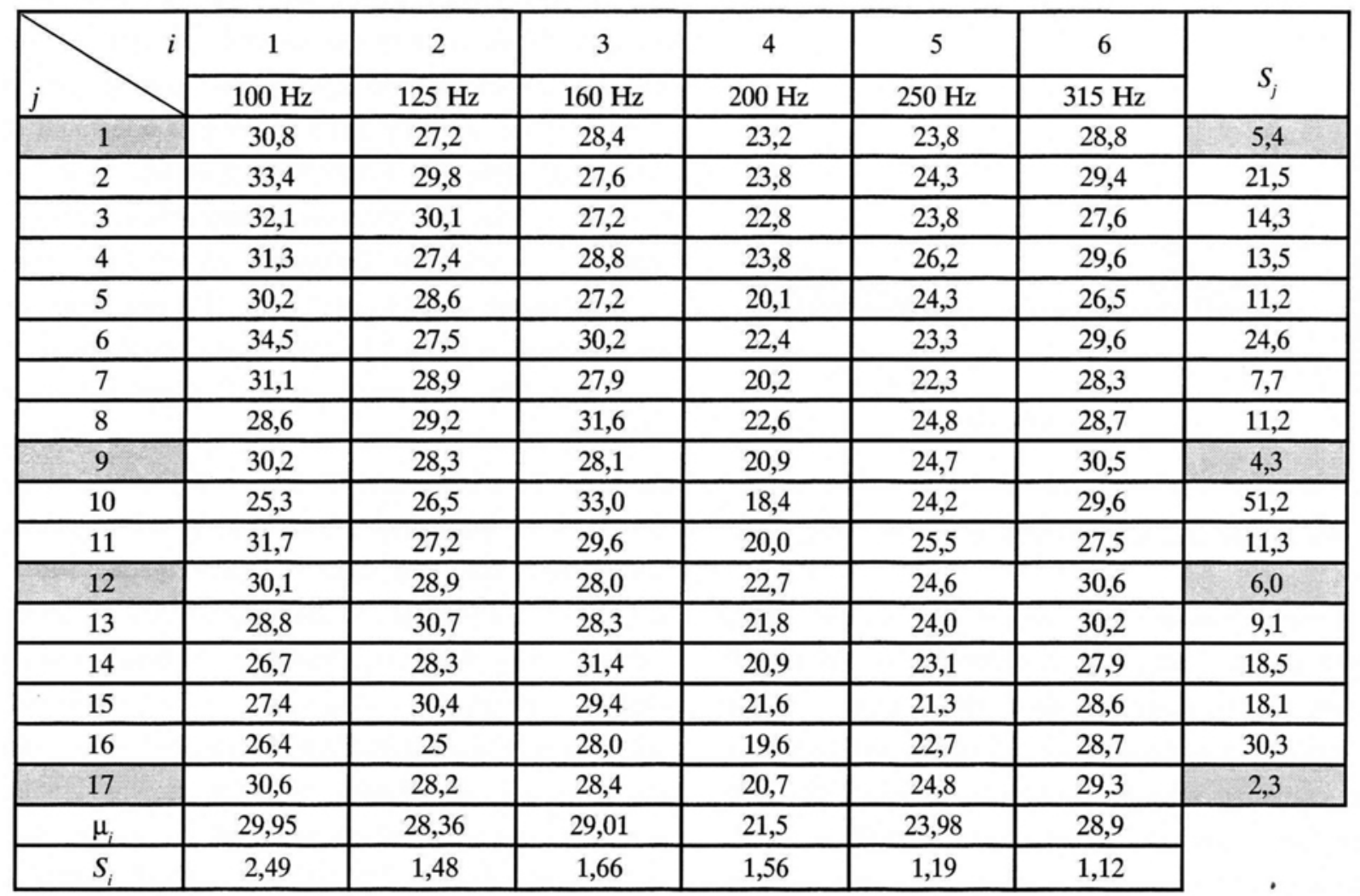


Kiekvienai garsiakalbio padèčiai buvo apskaičiuota $D_{i j}$ nuokrypiu nuo vidurkių $\mu_{i}$ kvadratu suma $S_{j}$ šešioms minètoms 1/3 oktavos dažnių juostoms pagal išraišką:

$$
S_{j}=\sum_{i=1}^{6}\left(D_{j i}-\mu_{i}\right)^{2} .
$$

Išmatuotos garso lygių skirtumu $D_{i j}$ vertès ir apskaičiuotų statistinių dydžių vertẻs pateiktos 1 lentelèje.

Remiantis 1 lentelès duomenimis, iš visut tirtu garsiakalbio vietų buvo pasirinktos keturios su mažiausiomis $S_{j}$ vertémis, t. y. $1,9,12,17$. Toliau, kaip rei- kalaujama standarte [3], iš šių pasirinktų poziciju buvo sudaromos $q$ pozicijų kombinacijos, kiekvienai iš kurių turi būti apskaičiuojamos nuokrypių nuo vidurkių kvadratı sumos $S_{j q}$ šešioms $1 / 3$ oktavos dažnio juostoms.

Šiuo atveju standarte egzistuoja neapibrèžtumas, kadangi neakcentuojama, kokių vidurkių atžvilgiu turètu būti skaičiuojami nuokrypiai. Ar tai yra generalinès aibès vidurkiai $\mu_{i}$, ar vidurkiai, apskaičiuoti kombinacijai? Taigi esant šiam neapibrèžtumui skaičiavome kiekvienos kombinacijos vidurkius ir tų vidurkių atžvilgiu skaičiavome nuokrypius, kadangi logiškiausia būtụ manyti, jog kombinacijų vidurkiai būtų mažiausiai paveik-

2 lentelè. $D_{i j}, S_{j g}$ reikšmès $\mathrm{A}, \mathrm{B}, \mathrm{C}, \mathrm{D}$ garsiakalbio padéčiu kombinacijoms

Table 2. $D_{i j}, S_{j g}$ values from A, B, C, D combinations of loudspeaker positions

\begin{tabular}{|c|c|c|c|c|c|c|c|c|}
\hline & \multirow[b]{2}{*}{$j$} & \multirow{2}{*}{$\frac{1}{100 \mathrm{~Hz}}$} & \multirow{2}{*}{$\frac{2}{125 \mathrm{~Hz}}$} & \multirow{2}{*}{$\frac{3}{160 \mathrm{~Hz}}$} & \multirow{2}{*}{$\frac{4}{200 \mathrm{~Hz}}$} & \multirow{2}{*}{$\frac{5}{250 \mathrm{~Hz}}$} & \multirow{2}{*}{$\frac{6}{315 \mathrm{~Hz}}$} & \multirow{2}{*}{$S_{j}$} \\
\hline & & & & & & & & \\
\hline \multirow{5}{*}{ A } & 1 & 30,8 & 27,2 & 28,4 & 23,2 & 23,8 & 28,8 & 4,06 \\
\hline & 17 & 30,6 & 28,2 & 28,4 & 20,7 & 24,8 & 29,3 & 1,11 \\
\hline & 9 & 30,2 & 28,3 & 28,1 & 20,9 & 24,7 & 30,5 & 1,81 \\
\hline & $\mu_{i, A}$ & 30,53 & 27,90 & 28,30 & 21,60 & 24,43 & 29,53 & \\
\hline & \multicolumn{4}{|c|}{$S_{j}=\sum_{i=1}^{6}\left(D_{j, i}-\mu_{i, A}\right)^{2}$} & \multicolumn{3}{|c|}{$S_{j, A}=\sum_{j=1}^{3} S_{j}=$} & 6,98 \\
\hline \multirow{5}{*}{ B } & 1 & 30,8 & 27,2 & 28,4 & 23,2 & 23,8 & 28,8 & 3,66 \\
\hline & 12 & 30,1 & 28,9 & 28,0 & 22,7 & 24,6 & 30,6 & 1,32 \\
\hline & 9 & 30,2 & 28,3 & 28,1 & 20,9 & 24,7 & 30,5 & 2,33 \\
\hline & $\mu_{i, B}$ & 30,37 & 28,13 & 28,16 & 22,27 & 24,37 & 29,97 & \\
\hline & \multicolumn{4}{|c|}{$S_{j}=\sum_{i=1}^{6}\left(D_{j, i}-\mu_{i, B}\right)^{2}$} & \multicolumn{3}{|c|}{$S_{j, B}=\sum_{j=\mathrm{l}}^{3} S_{j}=$} & 7,31 \\
\hline \multirow{5}{*}{$\begin{array}{l}\mathrm{C} \\
\mathrm{C}\end{array}$} & 9 & 30,2 & 28,3 & 28,1 & 20,9 & 24,7 & 30,5 & 0,46 \\
\hline & 12 & 30,1 & 28,9 & 28,0 & 22,7 & 24,6 & 30,6 & 2,55 \\
\hline & 17 & 30,6 & 28,2 & 28,4 & 20,7 & 24,8 & 29,3 & 1,45 \\
\hline & $\mu_{i, C}$ & 30,3 & 28,47 & 28,17 & 21,43 & 24,7 & 30,13 & \\
\hline & \multicolumn{4}{|c|}{$S_{j}=\sum_{i=1}^{6}\left(D_{j, i}-\mu_{i, C}\right)^{2}$} & \multicolumn{3}{|c|}{$S_{j, C}=\sum_{j=1}^{3} S_{j}=$} & 4,47 \\
\hline \multirow{5}{*}{$\mathrm{D}$} & 1 & 30,8 & 27,2 & 28,4 & 23,2 & 23,8 & 28,8 & 2,85 \\
\hline & 17 & 30,6 & 28,2 & 28,4 & 20,7 & 24,8 & 29,3 & 5,37 \\
\hline & 12 & 30,1 & 28,9 & 28,0 & 22,7 & 24,6 & 30,6 & 2,24 \\
\hline & $\mu_{i, D}$ & 30,50 & 28,10 & 28,26 & 22,20 & 24,40 & 29,56 & \\
\hline & \multicolumn{4}{|c|}{$S_{j}=\sum_{i=1}^{6}\left(D_{j, i}-\mu_{i, D}\right)^{2}$} & \multicolumn{3}{|c|}{$S_{j, D}=\sum_{j=1}^{3} S_{j}=$} & 10,46 \\
\hline
\end{tabular}


ti „,nevykusių“ garsiakalbio padečių lauko difuziškumo atžvilgiu, kurios tam tikru laipsniu lèmé generalinès aibés vidurkius $\mu_{i}$. Taigi naujai apskaičiuoti kombinacijų vidurkiai turètu geriau atspindéti maksimalu difuziškumą. Analizei buvo pasirinktos keturios kombinacijos, susidedančios iš trijų garsiakalbio paděčių. Jas sąlygiškai pažymëkime taip:
A) $1,17,9$;
B) $1,9,12$;
C) $9,12,17$;
D) $1,17,12$

Skaičiavimų rezultatai pateikti 2 lentelèje.

$\mu_{i, A}, \mu_{i, B}, \mu_{i, C}, \mu_{i, D}-D_{i j}$ vidurkiai, apskaičiuoti $i$-ajai $1 / 3$ oktavos dažnio juostai atitinkamai $\mathrm{A}$, B, C, D garsiakalbio poziciju kombinacijoms; $S_{j, A}$, $S_{j, B}, S_{j, C}, S_{j, D}-D_{i j}$ reikšmių nuokrypių nuo $\mu_{i, A}$, $\mu_{i, B}, \mu_{i, C}, \mu_{i, D}$ vidurkių kvadratı sumos atitinkamai $\mathrm{A}, \mathrm{B}, \mathrm{C}, \mathrm{D}$ garsiakalbio padéčiu kombinacijoms.

Kaip matome iš 2 lentelès, garsiakalbio poziciju kombinacija C priimtiniausia, kadangi $S_{j, C}$ vertè yra mažiausia.

\subsection{Garso izoliacijos indekso kartojimosi vertès $r$ patikra}

Vienas iš matavimų preciziškumo rodikliu yra kartojimosi vertè $\boldsymbol{r}$. Remiantis standarto [2] 5.1 punkto rekomendacijomis, buvo atlikti šeši bandymai matuojant to paties bandinio (plastikinio lango) garso izoliacijos indeksą šešiolikoje 1/3 oktavos dažnių juostų kartojimosi sąlygomis [2], naudojant $\mathrm{C}$ garsiakalbio poziciju kombinacija, nustatytą 3.3 poskyryje. Kartojimosi verte $\boldsymbol{r}$ visoms dažnio juostoms buvo apskaičiuota pagal formulę [2]:

$$
r=3,6 \sqrt{s_{r}^{2}}
$$

$s_{r}$ - kartojimosi standartinis nuokrypis, apskaičiuotas iš eksperimentinių duomenų. Šios pasikartojimo vertès laikomos patenkinamomis, jeigu $s_{r}$, vertès visose 16-oje 1/3 oktavos dažniu juostu tenkina nelygybę $s_{r} \leq m r_{\text {inter }}$, kur $m=0,68$, atlikus šešis bandymus [2]; $\boldsymbol{r}_{\text {inter }}$ yra kartojimosi vertès, nustatytos tarplaboratori-

3 lentelè. Statistiniai duomenys kartojimosi vertès $r$ patikrai

Table 3. Statistical data for verifying the repeatability value $r$

\begin{tabular}{|c|c|c|c|c|}
\hline$f, \mathrm{~Hz}$ & $s_{r}$ & $m r_{\text {inter }}$ & $\boldsymbol{r}_{\text {inter }}$ & $\boldsymbol{r}$ \\
\hline 100 & 0,16 & 3,06 & 4,5 & 0,58 \\
\hline 125 & 0,12 & 2,72 & 4 & 0,43 \\
\hline 160 & 0,24 & 2,38 & 3,5 & 0,86 \\
\hline 200 & 0,27 & 2,38 & 3,5 & 0,97 \\
\hline 250 & 0,30 & 1,70 & 2,5 & 1,08 \\
\hline 315 & 0,25 & 1,70 & 2,5 & 0,90 \\
\hline 400 & 0,34 & 1,36 & 2 & 1,22 \\
\hline 500 & 0,19 & 1,36 & 2 & 0,68 \\
\hline 630 & 0,22 & 1,02 & 1,5 & 0,78 \\
\hline 800 & 0,17 & 1,02 & 1,5 & 0,61 \\
\hline 1000 & 0,23 & 1,02 & 1,5 & 0,83 \\
\hline 1250 & 0,32 & 1,02 & 1,5 & 1,15 \\
\hline 1600 & 0,19 & 1,02 & 1,5 & 0,68 \\
\hline 2000 & 0,16 & 1,02 & 1,5 & 0,58 \\
\hline 2500 & 0,17 & 1,02 & 1,5 & 0,61 \\
\hline 3150 & 0,09 & 1,02 & 1,5 & 0,32 \\
\hline
\end{tabular}


niais bandymais su panašiu bandiniu, pateiktos A.1 lentelèje [2]. Visi apskaičiuoti statistiniai duomenys pateikti 3 lentelèje. Remiantis šiais duomenimis galima teigti, kad nelygybé $s_{r} \leq m r_{\text {inter }}$ visose $1 / 3$ oktavos dažniu juostose yra tenkinama, taigi kartojimosi verté $r$ gali būti laikoma patenkinama ir tai rodo, kad matavimai atlikti kokybiškai.

\section{Išvados}

1. Aidinčiu kamerų akustinių parametrų parinkimo tvarka nèra reglamentuota, todèl buvo atliktas šis eksperimentinis darbas.

2. Derinant kameru akustinius parametrus naudotos šios priemonès:

- garso sugèrikliai leido pasiekti reikiamas aidejjimo laiko reikšmes esant žemiesiems dažniams;

- difuzoriai, pakabinti kameru erdvèje, leido gauti reikiamą lauko difuziškumą aukštesnių dažnių diapazonu;

- didelių matmenu difuzorių j̇vertinimas leido sumažinti normalines žemujų dažnių modas ir padidinti lauko difuziškumą esant žemiesiems dažniams.

\section{Literatūra}

1. LST EN ISO 140-1. Akustika - Statinių atitvaru ir statinio daliu garso izoliavimo matavimas. 1-oji dalis. Laboratorinès bandymų ṫrangos, kurioje numalšintas garso perdavimas aplinkiniais keliais, reikalavimai (ISO 140-1:1997), 1999.

2. LST EN 20140-2. Akustika - Statiniu atitvarų ir statinio daliu garso izoliavimo matavimas. 2-oji dalis. Duomenu tikslumo nustatymas ir tikrinimas (ISO 140-2:1991), 1999.

3. LST EN ISO 140-3. Akustika - Statiniu atitvaru ir statinio daliu garso izoliavimo matavimas. 3-ioji dalis. Laboratoriniai statinio daliu oro garso izoliavimo matavimai (ISO 140-3:1995), 1999.

4. L. E. Kinsler, A. R. Frey, A. B. Coppens, J. V. Snaders. Fundamentals of Acoustic, New York: John Wiley\&Sons, 1982.

Iteikta 20000629
AN EXPERIMENTAL INVESTIGATION OF ACOUSTIC PARAMETERS OF THE LABORATORY FOR MEASURING SOUND INSULATION OF BUILDING ELEMENTS

\section{Dikavičius, R. Bliūdžius}

Sum mary

The report deals with a task of investigating and adjusting acoustic parameters of the reverberant chambers of recently built laboratory for measuring sound insulation properties of building elements (windows, doors).

The reverberation time values in the source and receiving empty rooms were measured at 16 one-third-octave frequency bands. It was determined that they significantly exceed the recommended ones. After a number of measurements the reverberation time was adjusted to the allowable limits.

An optimum combination of loudspeaker positions in the source room with respect to the best acoustic field diffusivity has been experimentally found.

Repeatability values $r$ were calculated from the measurements of sound reduction index of plastic window conducted under repeatability conditions. At the 16 one-third-octave frequency bands they show a good precision of the test equipment.

Vidmantas DIKAVIČIUS. Doctor. Research fellow of the building thermal physics laboratory at the Institute of Architecture and Construction, Tunelio g. 60, LT-3035 Kaunas, Lithuania. E-mail: silfiz@asi.lt

Kaunas polytechnical institute (1971, radio engineer). Doctor (1987, thesis about ultrasonic methods of high temperature gas flow). Co-author of 20 papers. Research interests: architectural acoustics, sound insulation measurements.

Raimondas BLIŪDŽIUS. Doctor. Senior research fellow. Laboratory of building thermal physics of the Institute of Architecture and Construction, Tunelio g. 60, LT-3035 Kaunas, Lithuania. E-mail: silfiz@asi.lt

A graduate of Vilnius Civil Engineering Institute (1989). Doctor (1995). Research interests: physical properties of building materials, research of physical-technical processes in building envelopes. 